\title{
SOCIAL STRUCTURE AND GROWTH RATE OF THE ARGENTINE-ANT Linepithema humile (Mayr, 1868)
}

\author{
Eduardo Diehl-Fleig ${ }^{1}$, Evoneo Berti Filho ${ }^{2}$, Odair Correa Bueno ${ }^{3} \&$ Elena Diehl ${ }^{4}$
}

${ }^{1}$ Escola Superior de Agricultura “Luiz de Queiroz”, USP. Piracicaba, Brasil. Bolsista de Mestrado - CNPq
2Pesquisador do CNPq, e-mail: eberti@ usp.br
${ }^{3}$ Universidade Estadual de Rio Claro, Brasil; Professor Titular UNESP; Pesquisador CNPq
${ }^{4}$ Pesquisadora CNPq; Professora Titular Aposentada, São Leopoldo, Brasil, e-mail: elenadiehl@pq.cnpq.br

ABSTRACT

This work evaluated the agonistic behavior among workers of different nests of the Argentineant Linepithema humile, the period of sexual production, the sexual proportion, the variation of intranest population in the summer and in the winter, and the growth rate of little colonies of 25 nests in Limeira, SP. The intranest population was determined by counting the individuals of ten nests, and the growth rate to dissemination with $10,50,100,150,200$, and 5Di00 workers. The Limeira population presented unicolonial social structure with no agonistic behavior among different nests. The sexual production was in the summer, with female-biased sexual investment (2.4:1). The size of the disseminates had a positive influence on the production of total offspring, but it was negative regarding the per capita production.

Keywords: Formicidae, agonistic behavior, intranidal population, sexual proportion

\section{ESTRUTURA SOCIAL E TAXA DE CRESCRIMENTO DA FORMIGA ARGENTINA Linepithema humile (Mayr, 1968)}

\section{RESUMO}

$\mathrm{Na}$ época da produção dos sexuados, foi avaliada a proporção sexual, bem como o comportamento agonístico entre operárias de ninhos distintos de Linepithema humilis, a variação da população intranidal no verão e no inverno, e a taxa de crescimento de pequenas colônias de 25 ninhos em Limeira, SP. A população intranidal foi determinada pela contagem dos indivíduos de dez ninhos, e a taxa de crescimento para propágulos com 10, 50, 100, 150, 200 e 500 operárias. A população de Limeira apresentou estrutura social unicolonial, com ausência de agressividade entre ninhos distintos. A produção 
de sexuados foi no verão, com investimento sexual a favor das fêmeas $(2,4: 1)$. O tamanho dos propágulos influenciou positivamente a produção de prole total e negativamente a produção per capita.

Palavras-chave: Formicidae, agressividade, população intranidal, proporção sexual

\section{INTRODUCTION}

The Argentine ant Linepithema humile (previously called Iridomyrmex humilis) is endogenous from the southern South America (SUAREZ; HOLWAY; CASE, 2001; TSUTSUI et al., 2001; WILD, 2004). It has been successful in Mediterranean and subtropical climate regions, although in temperate, tropical or excessively dry climate this ant seems unable to disperse and survive (PASSERA, 1994). Unfavorable areas, nevertheless, under the climatic perspective, can be rapidly colonized by this species as a result from these ants ability to follow men (WHEELER, 1925); that is why, according to Suarez et al. (2001), they are called tramp species.

Only a few ant species do not show aggressive intraspecific behavior, a characteristic which alows them to develop a unicolonial type of social structure, where the worker ants and the queen can move among the nests without aggression. This type of social structure is often found in introduced species that had become pests, but it is seldom found in native species. In surveys conducted in the southeast region of Brazil the Argentine ant was not found, or it was observed in very low densities (BUENO; CAMPOS-FARINHA, 1999; PIVA; CAMPOS-FARINHA, 1999). But this ant has shown high density at the rural area of Limeira municipality (RIBEIRO, 2004). In some households of Pelotas municipality in the south of Brazil, Silva and Loeck (1999) recorded high densities of the species.

Despite $L$. humile being a Brazilian endogenous species, practically there are no studies of this species biological and ecological aspects. Regarding the Argentine native populations, there are some studies showing occurrence of aggression among workers belonging to geographically distant nests, thus pointing to multicoloniality. The lack of agressivity allows for the development of one or more supercolonies, as seen in the state of California (TSUTSUI \& SUAREZ, 2003), whereas in south Europe a supercolony was recorded occupying by $6,000 \mathrm{~km}^{2}$ of the coastal region. The absence of aggressivity among worker ants belonging to distinctive colonies may be explained by the loss of genetic diversity occurring during their introduction and colonization of new environments, or by the fixation of recognition alleles (BOURKE \& FRANKS, 1995). 
Reproduction of L. humile colonies happens by sociotomy thus implying a slow invasion rate compared to those which present a mating flight. But the colonies are often introduced into new areas when goods are transported by men or by floodings (TSUTSUI \& SUAREZ, 2003). Therefore, these ants may invade unfavorable environments, such as mesic climate regions (HOLWAY et al., 1998; WILD, 2004). Hee et al. (2000), on their turn, observed a high growth rate in nests with a low number of workers.

In the invaded regions the Argentine ant brings about significant environmental, agricultural, and urban problems. It threatens species of endemic arthropods (WHEELER, 1925), and it has eliminated native ant species in California, Australia, and South Africa (ERICKSON, 1971; HOLWAY, 1995; HOLWAY et al., 1996, 1998). In South Africa this intruder substituted for the native ants responsible for seed dispersal, thus making it difficult the regeneration of endemic plant communities. Besides invading households they may damage agriculture since they are often associated with greenflies (SUDD \& FRANKS, 1995).

Despite analyses and comparisons that can be conducted on the biology of an invading species in the introduced environment and their own environment as well, such approach is still rare in L. humile (HOLWAY et al., 2002). Considering the just referred information, this study aimed at exploring the reproductive biology and the agonistic behavior among workers of distinctive nests of L. humile, and assessing the growth rate in small colonies. Specifically, it aimed at: 1) Assessing the aggressive behavior of intracolony and intercolony workers; 2) Determining the time sexual individuals are produced and the sexual rate; 3) Estimating the growth rate of small-sized colonies. Both colony growth and intraspecific aggressive behavior are significant biological features which must be considered for the success of control and management techniques of L. humile.

\section{MATERIAL AND METHODS}

The study area is located at the Tatu neighborhood (Limeira, São Paulo State), about $11 \mathrm{~km}$ far from the urban area. Collections were also carried out in Rio Claro and Piracicaba municipalities (SP). Sugar cane is the main plant cultivated in these regions. In 2004, 25 nests of L. humile were collected in these three regions, with the geographical coordinates measured for each nest, the distance between close nests, while the distance between distant nests was visually estimated, or through cartographic maps. Nests were excavated and the soil containing individuals was taken to the laboratory where there was separate, and the ants were transferred to the new nest, as reported by Keller et al. (1996). 
The artificial nests were built on Petri plates (12 cm round), and their bottom was plaster made in order to keep humidity. Each plate had two lateral holes working as a passage for the ants moving to the foraging area. The nests were distributed on a plastic tray $(58 \times 38 \times 11.5 \mathrm{~cm})$, with its margin covered by Fluon, and kept in a refrigerated room, a 12 -hour photoperiod, at $25^{\circ} \mathrm{C} \pm 1^{\circ} \mathrm{C}$ and $70-75 \%$ UR. Proteins, sugars, and carbohidrates were used as food. The water was provided ad libitum.

The intranidal population (queens, sexual individuals, eggs, larvae, pupae and worker ants) was assessed in ten nests, five during the summer, and five during the winter. The number of workers was estimated from the amount of workers occupying $1 \mathrm{~cm}^{3}$, with such value extrapolating their total volume.

The behavior assay was based on Holway et al. (1998) by assessing the following parameters: 0 = Ignore, physical contact when not any ant showed interest; 1 = Antennation, repeated antenna touch on the body of another ant; $2=$ Avoidance, one or both ants rapidly moving towards opposite directions after contact; 3 = Dorsal flexion, gaster rising into a vertical position (a behavior carried out when defense compounds are liberated); $4=$ Aggression, biting or pulling of the limbs or the head, or poison liberation; $5=$ Fight, lengthy aggressivity, usually arresting part of the body of the other ant by the jaw, or this other ant being taken.

Non-aggressive behavior is shown by 0-2 levels, whereas 3 to 5 levels point to aggressivity. From this tests it is possible to determine whether polydomy happens or not, that is, if one or more nests belong to the same colony, or if each nest is a different colony representant.

The time when sexual individuals are produced and the sexual production were observed over 12 months, and winged males and females development was assessed in five colonies, with assessment of copulation occurrence, sexual individuals' emergence, and sexual rate occurrence.

Regarding the growth rate, five colonies were used, each one with a queen and different sizes of propagules (10, 50, 100, 150, and 200 worker). All eggs, larvae and pupae of the artificial nests were removed before the beginning of the experiment. Two months later, the colonies were sacrified by freezing to allow for the counting of new individuals.

During data analysis, behavioral tests to investigate the relationship of the intraspecific aggressivity among colonies were compared by the Wilcoxon test. The growth rate was estimated by the per capita end production of the offspring (eggs, larvae, and pupae), by dividing this number by the living workers when the experiment was ended. For the per capita growth rate the final number of workers was divided by its starting number. Linear regression was used with log-transformed variables 
to determine the relationship between colony size and offspring's end production, and also to have the relationship of the offspring per capita production and the colony size assessed.

\section{RESULTS AND DISCUSSION}

Based on each nest's geographical coordenates (Table 1), the distance among the 11 nests of $L$. humile in the Limeira population showed some variation between $43 \mathrm{~m}$ and $2.800 \mathrm{~m}$, with $766 \mathrm{~m}$ as a mean distance among nest pairs (Box 1). The approximate distance between the Limeira population and the Rio Claro population was about $50 \mathrm{~km}$, and between Limeira and São Paulo it was about $120 \mathrm{~km}$. Table 2 shows the mean meteorological data of the collection times of L. humile nests in Limeira during the 2004 winter time and the 2005 summer time.

Table 1. Geographical coordinates of each nest (L=Limeira), 2004.

\begin{tabular}{ccc}
\hline & \multicolumn{2}{c}{ Geographical coordinates } \\
\cline { 2 - 3 } Nest & S & W \\
\hline L01 & $22^{\circ} 38^{\prime} 58.6^{\prime \prime}$ & $47^{\circ} 21^{\prime} 10.1^{\prime \prime}$ \\
L02 & $22^{\circ} 39^{\prime} 11.3^{\prime \prime}$ & $47^{\circ} 21^{\prime} 15.4^{\prime \prime}$ \\
L03 & $22^{\circ} 39^{\prime} 02.2^{\prime \prime}$ & $47^{\circ} 20^{\prime} 46.4^{\prime \prime}$ \\
L04 & $22^{\circ} 38^{\prime} 55.6^{\prime \prime}$ & $47^{\circ} 21^{\prime} 01.9^{\prime \prime}$ \\
L05 & $22^{\circ} 39^{\prime} 03.6^{\prime \prime}$ & $47^{\circ} 21^{\prime} 08.2^{\prime \prime}$ \\
L06 & $22^{\circ} 38^{\prime} 58.3^{\prime \prime}$ & $47^{\circ} 21^{\prime} 11.6^{\prime \prime}$ \\
L07 & $22^{\circ} 38^{\prime} 55.0^{\prime \prime}$ & $47^{\circ} 20^{\prime} 56.6^{\prime \prime}$ \\
L08 & $22^{\circ} 39^{\prime} 16.1^{\prime \prime}$ & $47^{\circ} 21^{\prime} 22.6^{\prime \prime}$ \\
L09 & $22^{\circ} 38^{\prime} 57.7^{\prime \prime}$ & $47^{\circ} 21^{\prime} 18.3^{\prime \prime}$ \\
L10 & $22^{\circ} 38^{\prime} 52.1^{\prime \prime}$ & $47^{\circ} 21^{\prime} 30.3^{\prime \prime}$ \\
L11 & $22^{\circ} 39^{\prime} 59.2^{\prime \prime}$ & $47^{\circ} 20^{\prime} 49.9^{\prime \prime}$ \\
\hline
\end{tabular}

Box 1. Distance (meters) among 11 nests of L. humile of the Limeira population Limeira (L), 2004.

\begin{tabular}{|c|c|c|c|c|c|c|c|c|c|c|}
\hline & L01 & L02 & L03 & L04 & L05 & L06 & L07 & L08 & L09 & L10 \\
\hline L01 & - & & & & & & & & & \\
\hline L02 & 401.8 & - & & & & & & & & \\
\hline L03 & 663.8 & 847.2 & - & & & & & & & \\
\hline L04 & 244.6 & 593.9 & 471.6 & - & & & & & & \\
\hline L05 & 157.2 & 314.4 & 602.7 & 297.0 & - & & & & & \\
\hline L06 & 43.7 & 401.8 & 707.5 & 279.5 & 183.4 & - & & & & \\
\hline L07 & 393.0 & 716.2 & 358.1 & 139.7 & 410.5 & 419.2 & - & & & \\
\hline L08 & 628.9 & 331.9 & $1,083.0$ & 838.5 & 541.5 & 611.4 & 952.0 & - & & \\
\hline L9 & 227.1 & 401.8 & 890.9 & 462.9 & 331.9 & 183.4 & 611.4 & 559.0 & - & \\
\hline L10 & 593.9 & 681.3 & $1,249.0$ & 786.1 & 698.7 & 550.2 & 943.3 & 742.4 & 375.6 & - \\
\hline L11 & $1,904.0$ & $1,589.6$ & $1,711.9$ & $1,921.5$ & $1,729.4$ & $1,904.0$ & $1,921.5$ & $1,572.1$ & $1,991.4$ & $2,288.3$ \\
\hline
\end{tabular}


Table 2. Mean meteorological data for nest collection times of Linepithema humile in Limeira population during the 2005 summer (Sum.), and the 2004 winter 2004 (Win.).

\begin{tabular}{|c|c|c|c|c|c|c|c|c|c|}
\hline \multirow{2}{*}{ Season } & \multirow{2}{*}{$\begin{array}{l}\text { Rainy } \\
\text { days }\end{array}$} & \multicolumn{2}{|c|}{$\begin{array}{l}\text { Rainfall } \\
(\mathrm{mm})\end{array}$} & \multicolumn{3}{|c|}{$\begin{array}{l}\text { Relative humidity } \\
\qquad(\%)\end{array}$} & \multicolumn{3}{|c|}{$\begin{array}{l}\text { Temperature } \\
\left({ }^{\circ} \mathrm{C}\right)\end{array}$} \\
\hline & & Daily & Monthly & Mean. & Max. & Min. & Mean & Max. & Min. \\
\hline Sum (1) & 14.6 & 4.57 & 139.37 & 85.78 & 98.0 & 70.0 & 24.67 & 30.0 & 18.99 \\
\hline Win (2) & 4.2 & 1.11 & 33.80 & 73.37 & 93.0 & 56.0 & 19.32 & 26.86 & 11.78 \\
\hline
\end{tabular}

In Limeira, a large portion of the observed interactions among the same nest workers right after collections was in correspondence with Ignoring and Antennation (87\%) behaviors. These two behavioral actions were also observed in most (93\%) of interactions among different nests of workers. Over this time there was no significant difference regarding the behavioral interactions between the workers belonging to different nests and the control nests (Mann Whitney, $U=345.5$, f.d. $=1, p=0.447$ ). When considering all 66 interactions between workers belonging to different nests and the same nests as separated treatments, not difference regarding aggression level was found (Kruskal Wallis, $\mathrm{H}=69.484$, f.d. $=65, \mathrm{p}=0.329)$.

Six to twelve months after collections, Ignore and Antennation were the most often observed behaviors among same-nest workers $(90 \% ; 88 \%)$ and different-nest workers (91\% and 92\%). Interactions between workers from different nests and the control nests were not significant either for six months (Mann Whitney, $U=296.5$, f.d. = 1, p = 0.915) or for twelve months (Mann Whitney, $U=341.0$, f.d. $=$ $1, p=0.495)$. By analysing all interactions between different nests and control nests of workers, that is, when the 66 treatments were considered, it was observed that the aggressivity level did not show significant variation over the first six months, (Kruskal Wallis, $\mathrm{H}=46.551$, f.d. $=65, \mathrm{p}=0.959$, or the twelve months (Kruskal Wallis, $\mathrm{H}=46.841$, f.d. $=65, \mathrm{p}=0.956$ ). Either the behavior of workers belonging to different nests or the behavior of workers belonging to the same nest showed no significant difference along assessment times (Kruskal Wallis, $\mathrm{H}=0.032$, f.d. $=2, \mathrm{p}=0.984$ ).

Regression of the mean aggressivity versus the distance among nests did not show a relationship between those variables (linear regression: $\mathrm{y}=-0.00005 \mathrm{x}+0.664, F_{1,53}=0.096, \mathrm{p}=0.758, \mathrm{r}^{2}=0.002$ ). 
Equally, when considering maximum aggressivity regression versus nests'distance there was no relationship between variables (linear regression: $\mathrm{y}=-0.00001 \mathrm{x}+1.215, F_{1,53}=0.040, \mathrm{p}=0.843, \mathrm{r}^{2}=$ $0.001)$.

Significant differences were observed regarding aggressivity level only when samples of $L$. humile populations from São Paulo and Rio Claro municipalities were considered. High aggressivity was seen among workers of Rio Claro population when compared to Limeira population (Mann Whitney, U $=300.0$, f.d. $=1, p=0.000)$. The interaction among workers of the São Paulo and the Limeira populations also resulted in high aggressivity (Mann Whitney, $U=0.0001$, f.d. $=1, \mathrm{p}=0.000$ ).

\section{Nest size and sexuals production}

When assessing the Limeira population, winged individuals were found only in February of 2004 and 2005, and in March and April of 2005, thus pointing to the summer as these individuals'development time. When considering winged individuals'nests $(n=5)$, a mean of 202.8 females and 83.6 males were observed. Since female production has always been higher than male production, the mean sexual proportion was $2.4: 1$, that is, female-biased $(\mathrm{t}=2.522$, f.d. $=8, \mathrm{p}=0.044)$. The mean sexual rate was 0.70 .

As a mean indicator, the workers intranest density in the summer was around 2.3 times higher than in the winter $(\mathrm{t}=5,207, \mathrm{f} . \mathrm{d} .=8, \mathrm{p}=0,002)$. The nests showed as a mean indication 79 queens over the summer, and 67 queens over the winter, and this difference was not significant $(\mathrm{t}=0.721, \mathrm{f} . \mathrm{d} .=8, \mathrm{p}$ $=0.492$ ). When summer and winter were compared, there was no significant difference for the offspring amount $(\mathrm{t}=0,220$, f.d. $=8, \mathrm{p}=0.832)$.

\section{Colony growth rate}

The total number of offspring brought about by propagules with more than ten early workers (50 - 500) was similar. But propagules with ten workers brought about less offspring than the ones with a larger number $\left(\mathrm{F}_{5,24}=13.848, \mathrm{p}=0.000\right)$. The total offspring increase showed a positive correlation with the propagules increase $\left(\mathrm{y}=0.416 \mathrm{x}+1.516, \mathrm{~F}_{1,28}=44.712, \mathrm{p}=0.000, \mathrm{r}^{2}=0.615\right)$. The production of per capita offspring was significantly different among the sizes of the early propagules $\left(\mathrm{F}_{5.24}=15.936, \mathrm{p}=\right.$ 
0.000), seeing that a negative correlation was found between the production of the per capita offspring and the propagules'size (regression line: $\mathrm{y}=-0.519 \mathrm{x}+1.377, \mathrm{~F}_{1.28}=50.056, \mathrm{p}=0.000, \mathrm{r}^{2}=0.641$ ).

When the early size of propagules was considered, no differences were observed regarding the per capita growth rates $\left(\mathrm{F}_{5.24}=0.807, \mathrm{p}=0.556\right)$. Also, there was no correlation between the growth rates and the early sizes of $L$. humile propagules $\left(\mathrm{F}_{1.28}=1.597, \mathrm{p}=0.217, \mathrm{r}^{2}=0.054\right)$.

Six to 12 months after collections of L. humile colonies in the Limeira population, the resulting numbers for the aggressivity tests among workers showed a 0 to 2 variation, pointing to the lack of intraspecific aggressivity, the same result obtained in tests made after collections. The majority of the noticed behaviors varied from Ignore and Antennation ( 0 e 1), with not any demonstration of aggressivity among workers from distinctive nests. Such absence of aggressivity was also noticed even among $L$. humile workers from as far as $2.2 \mathrm{~km}$-distant nests. Concomitantly, same-nest workers (control) showed three kinds of behaviors seen as non-aggressive (Ignore, Antennation, and Avoidance), with a prevalence of the first two behaviors.

No correlation of the distance among nests was found with values for mean aggressivity or even the maximum level for each pair of workers in the five repetitions, a data which point to the absence of association between these two variables. This finding stresses the early hypothesis that L. humile population from Vila Tatu (Limeira) shows a unicolonial type of social structure. Aggressivity was noticed only when the Limeira workers interacted with those from São Paulo or Rio Claro. This aggressivity was seen for all combinations among the 11 Limeira nests, with the addition of those of São Paulo and Rio Claro nests, indicative of multicoloniality.

The occurrence of a unicolonial type of social structure in the population of the Limeira Argentine ant could result from low genetic variation, as suggested for the L. humile populations introduced in different regions (KELLER et al., 1996; TSUTSUI \& SUAREZ, 2003). On its turn, this could be a result from the founder effect, and/or the genetic drift, thus leading to fixation of a few genotypes and, therefore, lower phenotypical diversity (HAMILTON, 1964; 1972), as occurring in other ant species populations (DIEHL, 1995). Thus, distinctive colonies of the same population could be genetically very similar, and, although occupying different nests, disregarding the distance between them, they could be seen as belonging to a supercolony.

Changes in the social structure of the Formicidae could also result from a reaction to highly disturbed environments, or even a strategy to colonize environments with low availability of nidification sites (HÖLLDOBLER \& WILSON, 1977). Many unicolonial species are found in areas which undergo 
disturbances and frequently change places as a reaction to environmental variations (HÖLLDOBLER \& WILSON, 1990). The social structure of the unicolonial type is expected for the species that dwell in flooding-prone areas (BOURKE \& FRANKS, 1995). The Argentine ant is regarded as native in the Parana River basin, seeing that in flooding plains of this river there is a great number of recordings of the existance of this ant. Unicoloniality, then, is an expected characteristic of these L. humile native populations.

Based on behavior and genetic differentiation, some authors suggested that L.humile populations in the native area would partly be multicolonial (TSUTSUI \& SUAREZ, 2003). But, in investigations of three populations along the Parana river in Argentina, based on the aggressivity levels of workers from different nests, aggressivity was not noticed in two populations, resulting in them being recorded as two supercolonies. The third population was characterized as multicolonial due to the high aggressivity among workers from nests less than $10 \mathrm{~m}$ far. This finding strengthens the hypothesis that the social structure of $L$. humile colonies in a native environment is flexible, fluctuating between multicolonial and unicolonial, as proposed by Ward (1987).

The social structure found in the population of the Limeira Argentine-ant can be a reaction against environmental conditions, since that, except for households and building areas, most of the areas show sugar cane fields. Such cultivated areas are burned during the winter, before being harvested, and this could result in major stress for the $L$. humile. Therefore, flexibility in the social structure is an inherent feature of species such as the Argentine-ant, with unicolonial populations being present as a reaction against ecological factors and, mainly, during invasions and colonization of new environments (BOURKE \& FRANKS, 1995). According to Nonacs and Soriano (1998), and Orr et al. (2001), in the unicolonial species large nests might be advantageous in highly competitive environments, since there is an expectation of the existence of a large number of workers to increase the colony ability to monopolize resource sources and their productivity, thus assuring the colony longevity and protecting it against predators and competitors. Life cycle of a large part of social insect colonies is characterized by the founding stage, when fertilized females settle new colonies. A few weeks or months from the foundation, there is the ergonomic stage when all the colony energy concentrates on its survival and growth by increasing the quantity of workers. When a certain size is achieved, a species-specific size, the colonies begin a reproduction stage, that is, new males and females are produced (OSTER \& WILSON, 1978; HÖLLDOBLER \& WILSON, 1990; DIEHL, 1995). 
The colonies foundation might be affected by the colonies early size (PAMILO, 1991a; b). But studies considering the colonies early size for the success of their foundation are rare. According to results obtained in this study, the minimum tested number of workers $(n=10)$ was enough for the increase of $L$. humile colony which showed up to 2.4 times its early size.

Disregarding the size of propagules tested in laboratory, Argentine-ant colonies survived and showed a mean growth rate always above 1.0. That is, even with the death of the workers, colonies kept their growth, with some propagules doubling their size. Nevertheless, in the field this pattern might not be noticed possibly as a function of some competition for feeding resources and favorable sites for nidification.

Small colonies'workers spend more time caring for the offspring than foraging (WILSON, 1951; KELLER et al., 1996) which leads to a fast growth of the colony. In this study this fact may account for the highest per capita offspring development in propagules of up to 50 workers, and a negative correlation between per capita production of offspring and number of workers. The low production of offspring noticed in the propagules with ten workers in relation to the other sizes (50 - 500 workers) seems to be related to the workers'ability to care for the offspring. The number of workers in the propagules did not result in significant increase of the total offpring production, which points to the queens'oviposition as independent from the number of workers (BOOMSMA \& GRAFEN, 1991). Such result shows that although not knowing the age and the physiological condition of the tested queens, the amount of laid eggs might be the same. But the small quantity of workers (10) was not enough to feed and care for all the queen's eggs.

The development of new colonies of $L$. humile occurs by sociotomy only, with very low survival of queens without the presence of workers (ARON \& PASSERA, 1999). In this study, propagules with ten workers showed a maximum growth rate of 2.4 , but this rate was not signficantly different from the other propagules.

Regarding the quantity of queens and offspring there was no significant difference among nests in the summer and in the winter. The intranidal population showed significant variation in the quantity of workers, being about 2.3 times higher than nests in the summer time. Markin (1970) also found a seasonal variation in the number of workers'nests of $L$. humile; nevertheless, the largest quantity of individuals was found in the winter. The intranidal population investigated by him was based on partial samples of each nest only, whereas nests of the Limeira population were totally assessed. 
In the Limeira population, the decreased number of workers can be related to the fall of the air relative humidity, and a decreased frequency and quantity of rainfall also, during the winter months. These changes of climatic conditions from season to season directly affect the workers when they are foraging, and/or indirectly affect them when they are inside the nests (MARKIN, 1970, NONACS \& SORIANO, 1998). Besides, rainfall decrease made water availability lower (THERAULAZ, 2001).

The original site of the Argentine-ant is the Parana river basin, an area characterized by frequent floods and water high availability, a totally different condition from the one found for the Limeira population. There are reports of higher survival of $L$. humile workers with air relative humidity higher than $90 \%$, and lower survival when they are exposed to a relative humidity of up to $80 \%$ for 24 hours. During the winter (June to September 2004), the minimum mean relative humidity recorded by the agrometereological station of Piracicaba was of $56 \%$, but it was of $36 \%$ in September (http://www.esalq.usp.br/departamentos/lce/postocon.html), which could have brought about the decrease of the workers.

An interesting genetic conflict between workers and queens in the eusocial Hymenoptera is resource allocation for the production of male or female offspring (BOOMSMA \& GRAFEN, 1991). This conflict was quantified by Trivers \& Hare (1976) in a theory comprising elements of the sexual proportion theory and the kinship theory (HAMILTON, 1964, 1972), and the parent-offspring conflict theory (TRIVERS, 1971). The authors raised the hypothesis that workers belonging to the eusocial species should profit from their kinship asimmetry regarding sexual offspring, thus leading to a sexual female-biased investment, while the adaptive value of the mother queen would be maximized at a sexual proportion of $1: 1$. If workers account for the control of sex allocation, female production is expected to be favored in a 3:1 rate, when all colony members are the offspring of only one monoandric queen.

It is expected that a decreased favoring of female production occurs concomitantly to a decrease of kinship assimmetry, both at population level and colony level (TRIVERS \& HARE, 1976; BOOMSMA \& GRAFEN, 1991; BOURKE \& FRANKS, 1995). Copulation of queens with more than one male is a seldom found event for L. humile, not detected in the already investigated queens yet. Besides, workers of the Argentine-ant are completely unable to produce eggs, even haploids (PASSERA, 1994). Kaufmann et al. (1992) assessed the kinship degree of same-nest queens and workers in a population of L. humilis in France, and they found that both the queens and the workers were not relatives. Thus, in colonies with high asimmetry one expects that the social investment is female-biased, with the sexual allocation control conducted by the workers (KELLER et al., 1996). 
Not before the nineties, studies started focusing on environmental factors possibly affecting sexual investment at colony level (ARON \& PASSERA, 1999). Among these already investigated factors there is food availability, seeing that when food is scarce the sexual investment favors male production, because males are usually smaller, thus requiring less energy to be produced. On the other hand, it is expected that in colonies with larger food availability a sexual investment occurs favoring female production (NONACS, 1985, 1986). This could be a second explanation for the sexual rate females biased noticed in the Limeira population.

In this study, probably the amount of protein offered to L. humile colonies in experimental nests was not enough or not adequate to develop the sexuals, or for the workers to decrease sexual offspring elimination, as suggested by Hölldobler and Wilson (1990). But in the experimental nests built on colonies from the Limeira population it was not noticed L. humile workers executing queens and/or sexual offspring, and dead queens were not found as well, contrary to what was reported by Markin, (1970), and Keller et al. (1996).

For Aron \& Passera, (1999), experimental data show that offspring selective elimination is a significant step in ant biology and other social insects. They also highlight the need to combine both approaches - kinship selection and life story - in the investigation of queen-worker conflicts in the dynamics of colony growth and sexual allocation.

\section{CONCLUSIONS}

The obtained data suggested that the Limeira population presents an unicolonial social structure, lacking aggressivity among workers from different nests. Sexuals individual production occurred in the summer with a female-biased sexual investment (2.4:1), whereas in the winter it was about half of the one recorded in the summer. Propagule size positively affected the total offspring production, and negatively affected the per capita production. The resulting data, not recorded for Brazil yet, should be widened and deepened, so that other subsidies are obtained for the control of the Argentine-ant in areas where the native species are being moved, besides damaging plant production.

\section{REFERENCES}

ARON, S.; PASSERA, L. 1999. Mode of colony foundation influences the primary sex ratio in ants. Animal Behavior, Oxford, v. 57, p. 325 - 329. 
BUENO, O.C.; CAMPOS-FARINHA, A.E.C. 1999. As formigas domésticas. In: MARICONI, F.A.M. (Ed.). Insetos e outros invasores de residências. Piracicaba: FEALQ, cap. 3, p. 135-180.

BOOMSMA, J.J.; GRAFEN, A. 1991. Intraspecific variation in ant sex ratios and the Trivers-Hare hypothesis. Evolution, New Jersey, v. 44. p. 1026 - 1034.

BOURKE, A. F. G.; FRANKS, N.R. 1995. Social Evolution in ants. Princeton University Press, New York, p. 519.

BRIAN, M.V. 1983. Social Insects. Ecology and Behavioural Biology. Chapman and

Hall, New York, p.377.

DIEHL, E. 1995. Formigas: Organização Social e Ecologia Comportamental.

Editora Unisinos, São Leopoldo, p.166.

ERICKSON, J.M. 1971. The displacement of native ant species by the introduced Argentine ant Iridomyrmex humilis Mayr. Psyche, Cambridge, v.78, p. 257 - 266.

HAMILTON, W. D. 1964. Genetical evolution of social behavior II. Journal of Theorical Biology, Amsterdam, v. 7, p. $354-356$.

HAMILTON, W. D. 1972. Altruism and related phenomena mainly in social insects. Ann. Rev. Ecol. Syst., Stanford, v. 3, p. 193 - 232.

HEE, J.J.; HOLWAY, D.A.; SUAREZ, A.V.; CASE, T.J. 2000. Role of propagule size

in the success of incipient colonies of the invasive Argentine ant. Conservation Biology, Oxford, UK, v. 14, n. 2, p. 559-563.

HÖLLDOBLER, B.; WILSON, E. O. 1977. The number of queens: an important trait in ant evolution.

Naturwissenschaften, Berlin, v. 64, p. 8 -15.

HÖLlBOBLER, B.; WILSON, E.O. 1990. The Ants. The Belknap Press of Harvard University press, Cambridge, Mass, $732 \mathrm{p}$.

HOLWAY, D.A. 1995. Distribution of the Argentine ant (Linipithema humile) in Northern California. Conservation Biology, Oxford, UK, v.9, p. 1634 - 1637.

HOLWAY, D.A.; HUMAN, K.; GORDON, D. 1996. Exploitative and interference competition between the Argentine ant and native ant species. Oecologia, Berlin, v.105, p. 405- 412.

HOLWAY, D.A., SUAREZ, A. V.; CASE, 1998. Loss of intraspecific aggression and the success of a widespread invasive social insect. Science, Washington, v. 282, p. 949 - 952.

HOLWAY, D. A.; LACH, L.; SUAREZ, A.V.; TSUTSUI, N. D.; CASE, T. J. 2002. Causes and consequences of ant invasions. Annual Review of Ecology and Systematics, Stanford, v. 33, p. 181 $-233$.

KAUFMANN, B.J., BOOMSA, J., PASSERA, L.; PETERSEN, K.N. 1992, Relatedness and inbreeding in a French population of the unicolonial ant Iridomyrmex humilis (Mayr). Insectes Sociaux, Paris, v. 39, n. 2, p. 195-213.

KELLER, L., L'HOSTE, G., BALLOUX, F.; PLUMEY, O. 1996. Queen number influences the primary sex ratio in the Argentine-ant, Linepithema humile (= Iridomyrmex humilis). Animal Behavior, Oxford, v. 51, p. 445 - 449.

MARKIN, G.P. 1970. Food distribution within laboratory nests of the Argentine-ant, Iridomyrmex humilis. Insectes Sociaux, Paris, v.17, p. $127-158$.

NONACS, P. 1985. Ant reproductive strategy and sex allocation theory. Quarterly Review of Biology, Chicago, v.61, p. $1-21$.

NONACS, P. V. 1986. Sex-ratio determination within colonies of ants. Evolution, New Jersey, v. 40, n. 1, p. $199-204$.

NONACS, P.; SORIANO, J.L. 1998. Patch sampling behavior and, future foraging expectations in Argentine ants, Linepithema humile. Animal Behavior, Oxford, v. 5, p. 519 -527. 
ORR, M.R., SEIKE, S.H., BENSON, W.W.; DAHLSTEN, D.L. 2001. Host specifity of Pseudaceton (Diptera: Phoridae) parasitoids that attack Linepithema humile (Hymenoptera: Formicidae) in South America. Environmental Entomology, College Park, v. 30, n. 4, p. 742 - 747.

OSTER, G. F.; WILSON, E. O. 1978. Caste and ecology in the social insects (Monographs in Population and Biology, n.12), Princeton University Press, 352 p.

PAMILO, P. 1991a. Evolution of colony characteristics in social insects. 1. Sex Allocation. American Naturalist, Chicago, v. 137, p. $83-107$.

PAMILO, P. 1991b. Evolution of colony characteristics in social insects. 2. Number of reproductives individuals. American Naturalist, Chicago, v.138, p. $412-433$.

PASSERA, L. 1994. Characteristics of tramp species. p. 23-43. In: I.D.F. WILLIAMS (ed). Exotic Ants:

Biology, Impact and Control of Introduced Species. Westwiew Press, Boulder, Colorado.

PIVA, A.; CAMPOS-FARINHA, A.E.C. 1999. Estrutura de comunidade das formigas urbanas do bairro de Vila Mariana na cidade de São Paulo. Naturalia, São Paulo, v. 24, n. esp., p. 115-117.

SILVA, E. J. E.; LOECK, A. E. 1999. Ocorrência de formigas domiciliares (Hymenoptera: Formicidae) em Pelotas, RS. Revista Brasileira de Agrociências, Pelotas, v. 5, n. 3, p. 220 - 224.

SUAREZ, A.V.; HOLWAY, D.A.; CASE, T.J. 2001. Patterns of spread in biological invasions dominated by long-jump dispersal: insights from Argentine-ants. Proceedings of the National Academy of Sciences of the United States of America, Washington DC, v. 98, n. 3, p. $1095-1100$.

SUDD, J. H.; FRANKS, N. R. 1987. The behavioural ecology of ants. Chapman and Hall, New York, 206p.

THERAULAZ, G. 2001. Model of droplet dynamics in the argentine ant Linepithema humile (Mayr). Bulletin of Mathematical Biology, Oxford, v. 63, p. 1079 - 1093.

TRIVERS, R. L. 1971. The evolution of reciprocal altruism. Quarterly Review of Biology, Chicago, V.46, n.1, p. $35-57$.

TRIVERS, R. L.; HARE, H. 1976. Haplodiploidy and the evolution of the social insects. Science, Washington, v.191, p. $249-263$.

TSUTSUI, N.D.; SUAREZ, A.V.; HOLWAY, D.A.; CASE, T.J. 2001. Relationships among native and introduced populations of the Argentine-ant (Linepithema humile) and the source of introduced populations. Molecular Ecology, Oxford, UK, v. 10, n. 9, p. 2151-2161.

TSUTSUI, N. D.; SUAREZ, A.V. 2003. The colony structure and population biology of invasive ants. Conservation Biology, Oxford, UK, v. 17, n. 1, p. $48-58$.

WARD, P. S. 1987. Distribution of the introduced Argentine-ant (Iridomyrmex humilis) in natural habitats of the lower Sacramento Valley and its effects on the indigenous ant fauna. Hilgardia, California, v.55, p. $1-16$.

WEBER, 1982, Fungus Ants p. 255 - 364. In: HERMANN, H. (ed.) Social Insects, v.IV, Academic Press, New York.

WHEELER, W. M. 1925. The Ants. Columbia Biological Series n.9. Columbia University, New York, $663 p$.

WILD, A.L. 2004. Taxonomy and distribution of the Argentine ant, Linepithema humile (Hymenoptera:

Formicidae). Annals of the Entomological Society of America, Lanham, v. 97, n. 6, p. 1204 - 1215.

WILSON, E. O. 1951, Variation and adaptation in the imported fire ant. Evolution, New Jersey, v. 9, p. $68-79$.

WILSON, E. O. 1971. The Insects Societies. Belknap Press of Harvard University. Press, Cambridge, Mass. 548p. 